Supplement of Geosci. Model Dev., 8, 733-768, 2015

http://www.geosci-model-dev.net/8/733/2015/

doi:10.5194/gmd-8-733-2015-supplement

(C) Author(s) 2015. CC Attribution 3.0 License.

(c) (i)

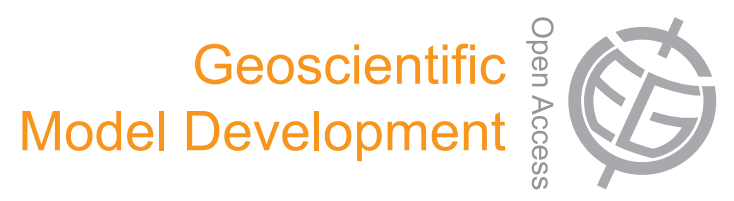

Supplement of

\title{
Quantitative evaluation of ozone and selected climate parameters in a set
} of EMAC simulations

M. Righi et al.

Correspondence to: M. Righi (mattia.righi@dlr.de) 
In this supplement, we provide additional information on the EMAC model simulations (Section S1) as well as additional figures to support the discussion in the paper (Section S2).

\section{S1 Additional information on EMAC simulations}

All four model setups consider boundary conditions for long-lived species, supplied to the model via the TNUDGE submodel (Kerkweg et al., 2006) and including greenhouse gases $\mathrm{CO}_{2}$, $\mathrm{N}_{2} \mathrm{O}, \mathrm{CH}_{4}$, chlorofluorocarbons $\left(\mathrm{CFCl}_{3}, \mathrm{CF}_{2} \mathrm{Cl}_{2}, \mathrm{CH}_{3} 3 \mathrm{CCl}_{3}, \mathrm{CCl}_{4}\right)$, hydrochlorofluorocarbons $\left(\mathrm{CH}_{3} \mathrm{Cl}, \mathrm{CH}_{3} \mathrm{Br}\right)$, halons $\left(\mathrm{CF}_{2} \mathrm{ClBr}, \mathrm{CF}_{3} \mathrm{Br}\right)$ and $\mathrm{H}_{2}$. The input fields (monthly-mean, zonally averaged mixing ratios) are taken from the AGAGE database (Prinn et al., 2000). Emissions of short-lived species (NO, CO, $\mathrm{SO}_{2}, \mathrm{NH}_{3}$ and NMHCs $\mathrm{C}_{2} \mathrm{H}_{4}, \mathrm{C}_{2} \mathrm{H}_{6}, \mathrm{C}_{3} \mathrm{H}_{6}, \mathrm{C}_{3} \mathrm{H}_{8}, \mathrm{C}_{4} \mathrm{H}_{10}$, $\mathrm{CH}_{3} \mathrm{CHO}, \mathrm{CH}_{3} \mathrm{COCH}_{3}, \mathrm{CH}_{3} \mathrm{COOH}, \mathrm{CH}_{3} \mathrm{OH}, \mathrm{HCHO}, \mathrm{HCOOH}$ ), methyl ethyl ketone (MEK)) are provided to the model as offline fields via the OFFLEM/OFFEMIS submodel (Kerkweg et al., 2006). We consider anthropogenic (traffic and non-traffic) source from different datasets, and natural sources like volcanic $\mathrm{SO}_{2}$ (from AeroCom; Dentener et al., 2006), terrestrial DMS (Spiro et al., 1992) and biogenic sources (Guenther et al., 1995).

NMHC speciation is realized according to the speciation fraction by von Kuhlmann et al. (2003). Different fractions are used for biomass burning and anthropogenic emissions. NMHC mass (usually $\mathrm{kg}(\mathrm{NMHC})$ ) is converted to carbon mass $(\mathrm{kg}(\mathrm{C})$ ) assuming a ratio of $161 / 210$, as suggested in the IPCC third assessment report (see also Hoor et al., 2009). In a test simulation (not discussed here), the speciation provided in the inventory by Lamarque et al. (2010) has also been considered, but due to its inconsistency with the chemical mechanism of our model, it led to unrealistic results in comparison with the tropospheric vertical profiles from Emmons et al. (2000). Therefore the above method was preferred and applied in all of the simulations presented here. Anthropogenic (except aviation) and biomass burning emissions are distributed in the vertical using 6 layers $(45,140,240,400,600,800 \mathrm{~m})$ following the suggestions of Pozzer et al. (2009), mostly based on EMEP. Aviation emission levels are provided by the corresponding inventory (in the range 0-15 km). Volcanic emissions are distributed according to the volcano height. Other sources are emitted as two-dimensional surface fluxes and no assumption on the injection height is therefore required.

The model also simulates online emissions of isoprene and soil NO, via the ONLEM/ONEMIS submodel. The exchange of species between the atmosphere and the ocean is simulated by the AIRSEA submodel (Pozzer et al., 2006), based on the concentration of isoprene (Broadgate et al., 1997), oceanic DMS (Kettle and Andreae, 2000) as well as the ocean salinity (Boyer et al., 2002). Solar cycle data for the calculation of the photolysis rates in the JVAL submodel are taken from Lean (2000). Finally, lightning $\mathrm{NO}_{\mathrm{x}}$ emissions are calculated online by the LNOX submodel using different parametrization. A summary of boundary conditions, emissions and other data required by the model in the four setups is given in Table S1. The simulations discussed here do not include aerosols, therefore the standard ECHAM5 aerosol climatology (Tanre et al., 1994) is used to drive the radiation calculations. 
Table S1: Boundary conditions and emission datasets for the EMAC simulations. References to each dataset/inventory are given in the text. A specification whether data are used in transient or in constant (2000) mode is given for each dataset. The abbreviation SB97 refers to the inventory by Schmitt and Brunner (1997). M7 is the aerosol model by Vignati et al. (2004) providing aerosol surface concentrations for heterogeneous chemistry reactions.

\begin{tabular}{|c|c|c|c|c|c|}
\hline & MESSy submodel & EVAL2 & QCTM & TS2000 & ACCMIP \\
\hline \multirow{2}{*}{$\begin{array}{l}\text { Concentrations of } \\
\text { long-lived species }\end{array}$} & \multirow{2}{*}{ TNUDGE } & \multicolumn{4}{|c|}{ AGAGE } \\
\hline & & Transient & Transient & 2000 & 2000 \\
\hline \multirow{2}{*}{$\begin{array}{l}\text { Biomass burning } \\
\text { emissions }\end{array}$} & OFFLEM/ & GFED & GFED & CMIP5 & CMIP5 \\
\hline & OFFEMIS & Transient & Transient & 2000 & 2000 \\
\hline \multirow{2}{*}{$\begin{array}{l}\text { Agric. waste burning } \\
\text { emissions }\end{array}$} & OFFLEM/ & \multicolumn{4}{|c|}{ CMIP5 } \\
\hline & OFFEMIS & 2000 & 2000 & 2000 & 2000 \\
\hline \multirow{2}{*}{$\begin{array}{l}\text { Anthrop. non-traffic } \\
\text { emissions }\end{array}$} & OFFLEM/ & \multicolumn{4}{|c|}{ CMIP5 } \\
\hline & OFFEMIS & \multicolumn{4}{|c|}{2000} \\
\hline \multirow{2}{*}{$\begin{array}{l}\text { Land transport } \\
\text { emissions }\end{array}$} & OFFLEM/ & QUANTIFY & QUANTIFY & CMIP5 & CMIP5 \\
\hline & OFFEMIS & 2000 & 2000 & 2000 & 2000 \\
\hline \multirow{2}{*}{$\begin{array}{l}\text { Shipping } \\
\text { emissions }\end{array}$} & OFFLEM/ & \multicolumn{4}{|c|}{ CMIP5 } \\
\hline & OFFEMIS & Transient & \multirow{3}{*}{$\begin{array}{c}\text { Transient } \\
\text { QUANTIFY } \\
2000 \\
\end{array}$} & 2000 & 2000 \\
\hline \multirow{2}{*}{$\begin{array}{l}\text { Aviation } \\
\text { emissions }\end{array}$} & OFFLEM/ & \multirow{2}{*}{$\begin{array}{c}\text { SB97 } \\
\text { Transient }\end{array}$} & & QUANTIFY & CMIP5 \\
\hline & OFFEMIS & & & 2000 & 2000 \\
\hline \multirow{2}{*}{$\begin{array}{l}\text { Biogenic } \\
\text { emissions }\end{array}$} & OFFLEM/ & \multicolumn{4}{|c|}{ Guenther et al. (1995) } \\
\hline & OFFEMIS & 2000 & 2000 & 2000 & 2000 \\
\hline \multirow{2}{*}{$\begin{array}{l}\text { Volcanic } \\
\text { emissions }\end{array}$} & OFFLEM/ & \multicolumn{4}{|c|}{ AeroCom } \\
\hline & OFFEMIS & 2000 & 2000 & 2000 & 2000 \\
\hline \multirow{2}{*}{$\begin{array}{l}\text { Terrestrial DMS } \\
\text { emissions }\end{array}$} & OFFLEM/ & \multicolumn{4}{|c|}{ Spiro et al. (1992) } \\
\hline & OFFEMIS & 2000 & \multirow{3}{*}{$\begin{array}{c}2000 \\
\text { EDGAR } \\
2000\end{array}$} & 2000 & 2000 \\
\hline \multirow{2}{*}{$\begin{array}{l}\mathrm{NH}_{3} \\
\text { emissions }\end{array}$} & OFFLEM/ & \multirow{2}{*}{$\begin{array}{c}\text { EDGAR } \\
2000 \\
\end{array}$} & & CMIP5 & CMIP5 \\
\hline & OFFEMIS & & & 2000 & 2000 \\
\hline \multirow{3}{*}{$\begin{array}{l}\text { Isoprene emissions } \\
\text { Oceanic DMS emissions } \\
\text { Ocean salinity }\end{array}$} & AIRSEA & & Broadgate et & $(1997)$ & \\
\hline & AIRSEA & & Kettle and An & ae $(2000)$ & \\
\hline & AIRSEA & & Boyer et a & 2002) & \\
\hline Aerosol (radiation) & - & & Tanre et a & $994)$ & \\
\hline Aerosol (chemistry) & - & M7 & & included & \\
\hline QBO & QBO & Giorgetta and & Bengtsson (1999 & Not inc & ided \\
\hline & & & Lean $(2$ & & \\
\hline Solar cycle & JVAL & Transient & 2000 & 2000 & 2000 \\
\hline Lightning $\mathrm{NO}_{\mathrm{x}}$ & LNOX & Price anc & Rind (1994) & Grewe et a & $(2001)$ \\
\hline Nudging & - & & MWF & Not inc & ided \\
\hline
\end{tabular}


Table S2: Total emissions for different species and sectors in the four EMAC simulations. For transient emissions, minimum and maximum values for the simulated period (excluding the spin-up year) are given. For constant emission, the value refers to the year 2000, whereas for online emissions the average value is provided. Natural sources emissions of $\mathrm{NO}_{\mathrm{x}}$ include also lightning emissions, given in brackets in the corresponding column. Units are $\mathrm{Tg}(\mathrm{species}) / \mathrm{yr}$ and $\mathrm{Tg}(\mathrm{NO}) / \mathrm{yr}$ for $\mathrm{NO}$. See Table $\mathrm{S} 1$ for the corresponding emission inventories. $\mathrm{NH}_{3}$ emissions per sector are available only for the ACCMIP run, in the other cases only the total value is given in the last row.

\begin{tabular}{|c|c|c|c|c|c|c|c|c|c|}
\hline Sector & Experiment & $\mathrm{NO}_{\mathrm{x}}$ & $\mathrm{CO}$ & $\mathbf{S O}_{2}$ & $\mathbf{N H}_{3}$ & $\mathbf{C}_{2} \mathbf{H}_{4}$ & $\mathbf{C}_{2} \mathbf{H}_{6}$ & $\mathbf{C}_{3} \mathbf{H}_{6}$ & $\mathbf{C}_{3} \mathbf{H}_{8}$ \\
\hline \multirow{4}{*}{$\begin{array}{l}\text { Biomass and agric. } \\
\text { waste burning }\end{array}$} & EVAL2 & $7.87-11.19$ & $270.74-403.71$ & $1.85-2.80$ & - & $3.08-4.25$ & $1.75-2.42$ & $1.38-1.90$ & $0.55-0.75$ \\
\hline & QCTM & $7.87-11.19$ & $270.74-403.71$ & $1.85-2.80$ & - & $3.08-4.25$ & $1.75-2.42$ & $1.38-1.90$ & $0.55-0.75$ \\
\hline & TS2000 & 8.54 & 285.31 & 2.04 & - & 3.27 & 1.86 & 1.47 & 0.58 \\
\hline & ACCMIP & 12.06 & 476.76 & 4.03 & 11.73 & 13.73 & 7.83 & 6.13 & 2.44 \\
\hline \multirow{4}{*}{$\begin{array}{l}\text { Anthropogenic non- } \\
\text { traffic sources }\end{array}$} & EVAL2 & 32.88 & 364.66 & 88.03 & - & 3.15 & 5.43 & 1.33 & 8.40 \\
\hline & QCTM & 32.88 & 364.66 & 88.03 & - & 3.15 & 5.43 & 1.33 & 8.40 \\
\hline & TS2000 & 32.88 & 364.66 & 88.03 & - & 3.15 & 5.43 & 1.33 & 8.40 \\
\hline & ACCMIP & 32.88 & 364.66 & 88.03 & 36.27 & 3.15 & 5.43 & 1.33 & 8.40 \\
\hline \multirow{4}{*}{ Traffic sources } & EVAL2 & $31.75-37.09$ & $111.23-111.82$ & $12.12-16.69$ & - & $0.59-0.63$ & $1.01-1.08$ & $0.25-0.26$ & $1.57-1.68$ \\
\hline & QCTM & $32.11-36.95$ & $111.23-111.82$ & $12.12-16.69$ & - & $0.59-0.63$ & $1.01-1.08$ & $0.25-0.26$ & $1.57-1.68$ \\
\hline & TS2000 & 32.93 & 111.62 & 12.94 & - & 0.60 & 1.03 & 0.25 & 1.59 \\
\hline & ACCMIP & 36.78 & 223.55 & 15.33 & 0.47 & 1.16 & 2.00 & 0.49 & 3.09 \\
\hline \multirow{4}{*}{$\begin{array}{l}\text { Natural } \\
\text { sources } \\
\text { (lightning) }\end{array}$} & EVAL2 & $23.66(11.03)$ & 112.80 & 30.69 & - & 11.38 & 0.54 & 3.42 & 0.35 \\
\hline & QCTM & $16.52(3.81)$ & 112.80 & 30.69 & - & 11.38 & 0.54 & 3.42 & 0.35 \\
\hline & TS2000 & $23.50(10.67)$ & 112.80 & 30.69 & - & 11.38 & 0.54 & 3.42 & 0.35 \\
\hline & ACCMIP & $25.31(12.39)$ & 112.80 & 30.69 & - & 11.38 & 0.54 & 3.42 & 0.35 \\
\hline \multirow{4}{*}{ Total } & EVAL2 & $97.26-103.37$ & $858.42-991.64$ & $132.75-137.56$ & 65.27 & $18.17-19.37$ & $8.74-9.44$ & $6.36-6.89$ & $10.87-11.14$ \\
\hline & QCTM & $87.12-96.29$ & $858.42-991.64$ & $132.75-137.56$ & 65.27 & $18.17-19.37$ & $8.74-9.44$ & $6.36-6.89$ & $10.87-11.14$ \\
\hline & TS2000 & 97.86 & 874.38 & 133.69 & 65.27 & 18.40 & 8.86 & 6.46 & 10.92 \\
\hline & ACCMIP & 106.68 & 1177.77 & 138.08 & 48.46 & 29.43 & 15.80 & 11.36 & 14.28 \\
\hline Sector & Experiment & $\mathbf{C}_{4} \mathbf{H}_{10}$ & $\mathrm{CH}_{3} \mathrm{CHO}$ & $\mathrm{CH}_{3} \mathrm{COCH}_{3}$ & $\mathrm{CH}_{3} \mathrm{COOH}$ & $\mathbf{C H}_{3} \mathrm{OH}$ & НСНО & НСООН & MEK \\
\hline \multirow{4}{*}{$\begin{array}{l}\text { Biomass and agric. } \\
\text { waste burning }\end{array}$} & EVAL2 & $0.69-0.96$ & $1.23-1.69$ & $1.12-1.55$ & $3.93-5.43$ & $3.96-5.47$ & $2.10-2.90$ & $2.15-2.96$ & $2.66-3.67$ \\
\hline & QCTM & $0.69-0.96$ & $1.23-1.69$ & $1.12-1.55$ & $3.93-5.43$ & $3.96-5.47$ & $2.10-2.90$ & $2.15-2.96$ & $2.66-3.67$ \\
\hline & TS2000 & 0.74 & 1.31 & 1.19 & 4.18 & 4.21 & 2.23 & 2.28 & 2.82 \\
\hline & ACCMIP & 3.12 & 5.48 & 4.99 & 17.54 & 17.71 & 9.40 & 9.57 & 11.88 \\
\hline \multirow{4}{*}{$\begin{array}{l}\text { Anthropogenic non-- } \\
\text { traffic sources }\end{array}$} & EVAL2 & 62.82 & - & 2.78 & - & 2.78 & 0.87 & - & 3.75 \\
\hline & QCTM & 62.82 & - & 2.78 & - & 2.78 & 0.87 & - & 3.75 \\
\hline & TS2000 & 62.82 & - & 2.78 & - & 2.78 & 0.87 & - & 3.75 \\
\hline & ACCMIP & 62.82 & - & 2.78 & - & 2.78 & 0.87 & - & 3.75 \\
\hline \multirow{4}{*}{ Traffic sources } & EVAL2 & $11.74-12.55$ & - & $0.52-0.55$ & - & $0.52-0.55$ & $0.16-0.17$ & - & $0.70-0.75$ \\
\hline & QCTM & $11.74-12.55$ & - & $0.52-0.55$ & - & $0.52-0.55$ & $0.16-0.17$ & - & $0.70-0.75$ \\
\hline & TS2000 & 11.91 & - & 0.53 & - & 0.53 & 0.17 & - & 0.72 \\
\hline & ACCMIP & 23.13 & - & 1.03 & - & 1.03 & 0.32 & - & 1.39 \\
\hline \multirow{4}{*}{$\begin{array}{l}\text { Natural } \\
\text { sources }\end{array}$} & EVAL2 & 0.40 & - & 55.82 & 3.39 & 150.71 & - & 5.59 & - \\
\hline & QCTM & 0.40 & - & 55.82 & 3.39 & 150.71 & - & 5.59 & - \\
\hline & TS2000 & 0.40 & - & 55.82 & 3.39 & 150.71 & - & 5.59 & - \\
\hline & ACCMIP & 0.40 & - & 55.82 & 3.39 & 150.71 & - & 5.59 & - \\
\hline \multirow{4}{*}{ Total } & EVAL2 & $75.65-76.54$ & $1.23-1.69$ & $60.12-60.58$ & $7.32-8.82$ & $157.63-159.16$ & $3.13-3.94$ & $7.72-8.54$ & $7.11-8.15$ \\
\hline & QCTM & $75.65-76.54$ & $1.23-1.69$ & $60.12-60.58$ & $7.32-8.82$ & $157.63-159.16$ & $3.13-3.94$ & $7.72-8.54$ & $7.11-8.15$ \\
\hline & TS2000 & 75.87 & 1.31 & 60.32 & 7.57 & 158.22 & 3.27 & 7.87 & 7.29 \\
\hline & ACCMIP & 89.48 & 5.48 & 64.61 & 20.93 & 172.22 & 10.59 & 15.16 & 17.02 \\
\hline
\end{tabular}




\section{S2 Additional figures}
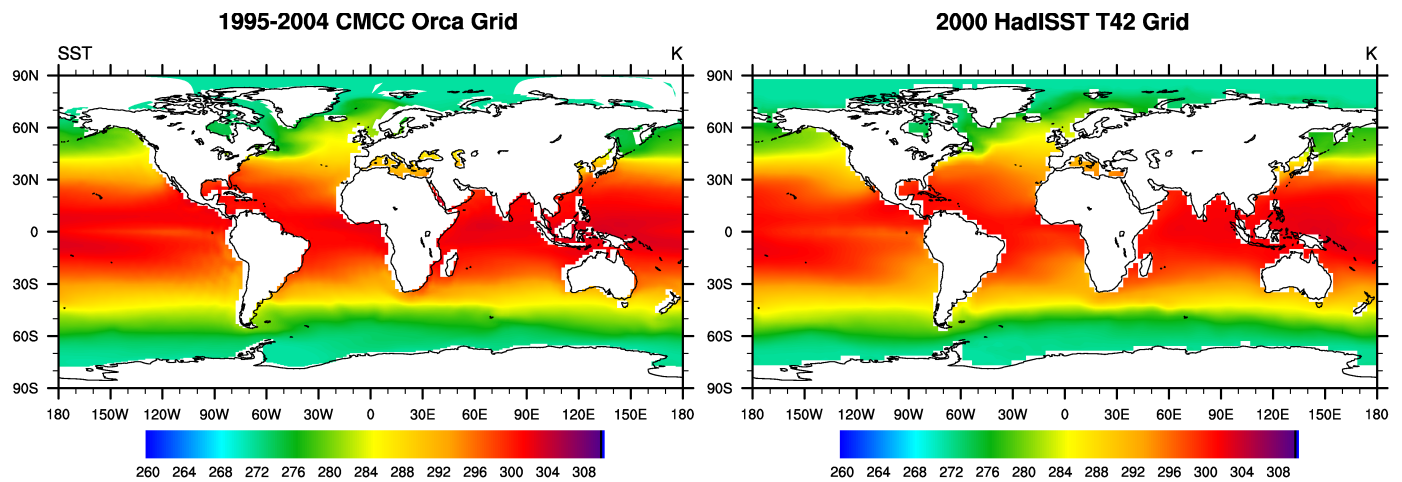

1995-2004 CMCC T42 Grid masked

Differences (HadISST - CMCC)

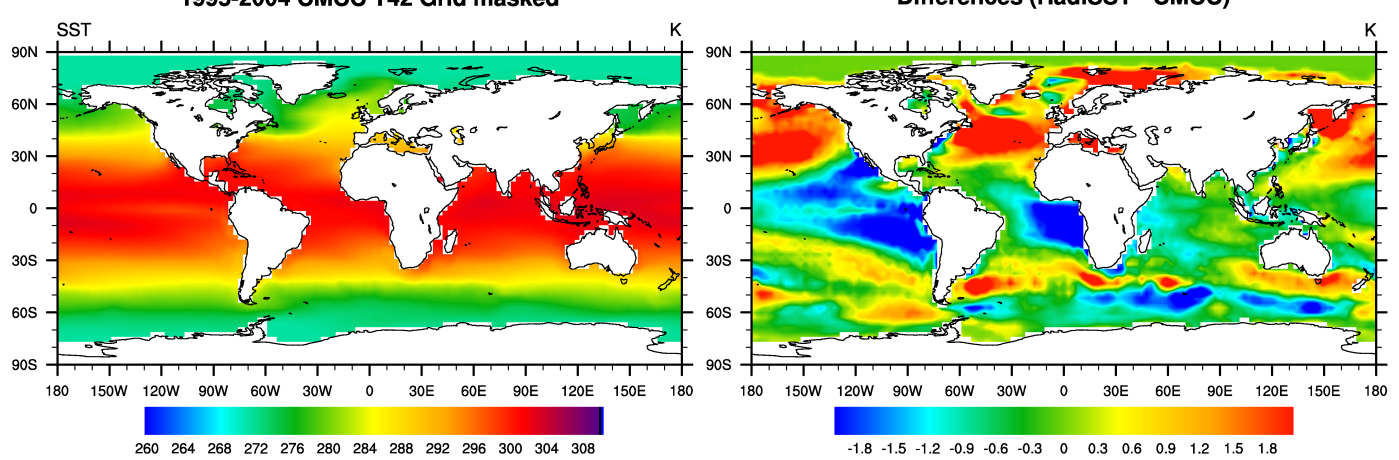

Figure S1: Annual mean sea surface temperature climatology in K (1995-2004) as simulated with the CMCC Climate Model (historical CMIP5 simulation) compared to HadISST used in the ACCMIP and TS2000 simulations, respectively. Top left: CMCC SICs on the ORCA coordinates interpolated to a T42 grid; Top right: HAdIIST data on a T42 grid; Bottom left: CMCC SICs in T42 masked with the ECHAM sea-land mask; Bottom right: differences between HAdIIST data on a T42 grid and CMCC SICs in T42 masked with the ECHAM sea-land mask. 

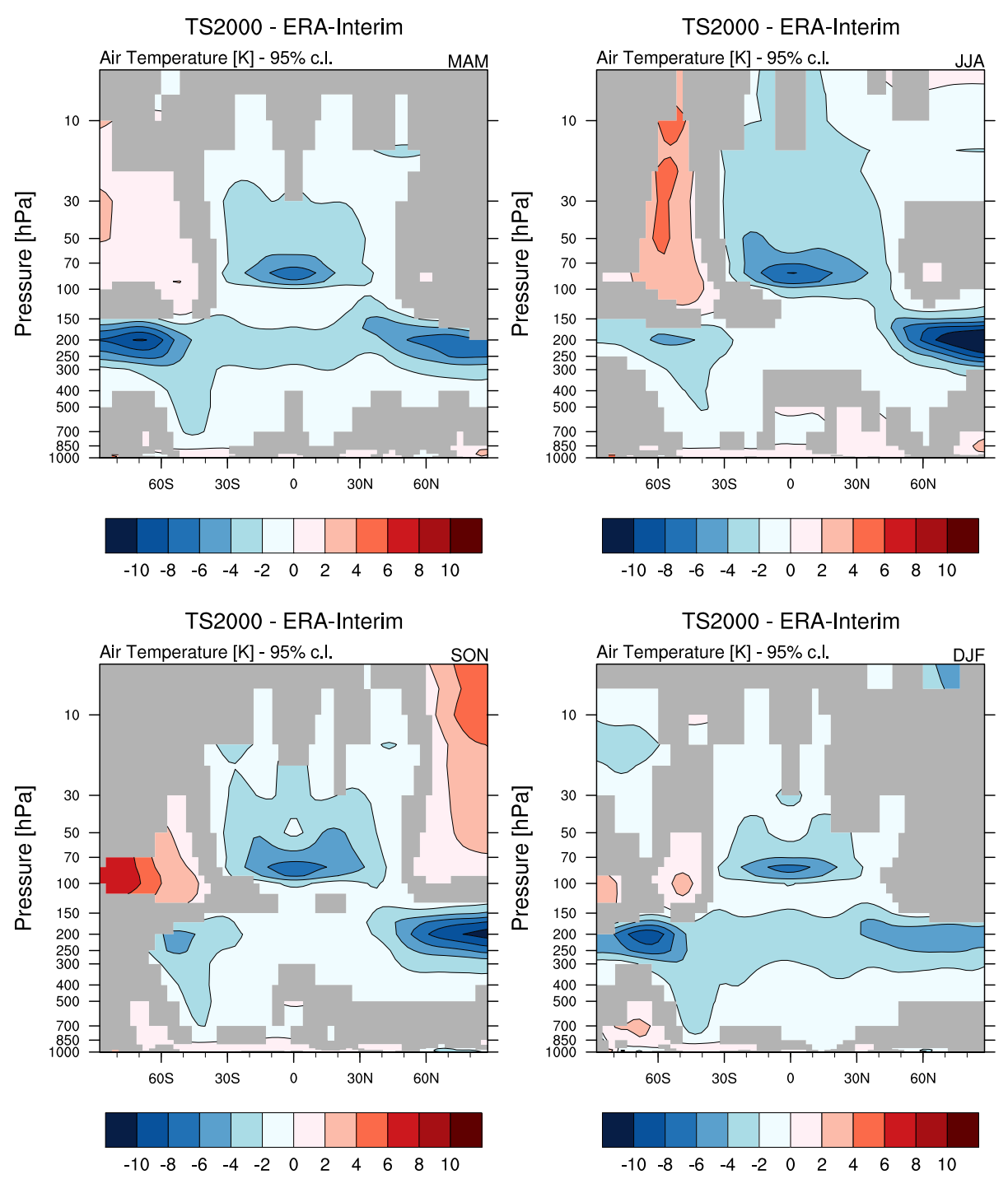

Figure S2: Seasonal mean of zonally averaged temperature profile for the TS2000 simulation in comparison to ERA-Interim. Clockwise from top-left: MAM, JJA, DJF, SON. Differences between the two fields that are not statistically significant according to the $95 \%$ confidence level are marked gray. 

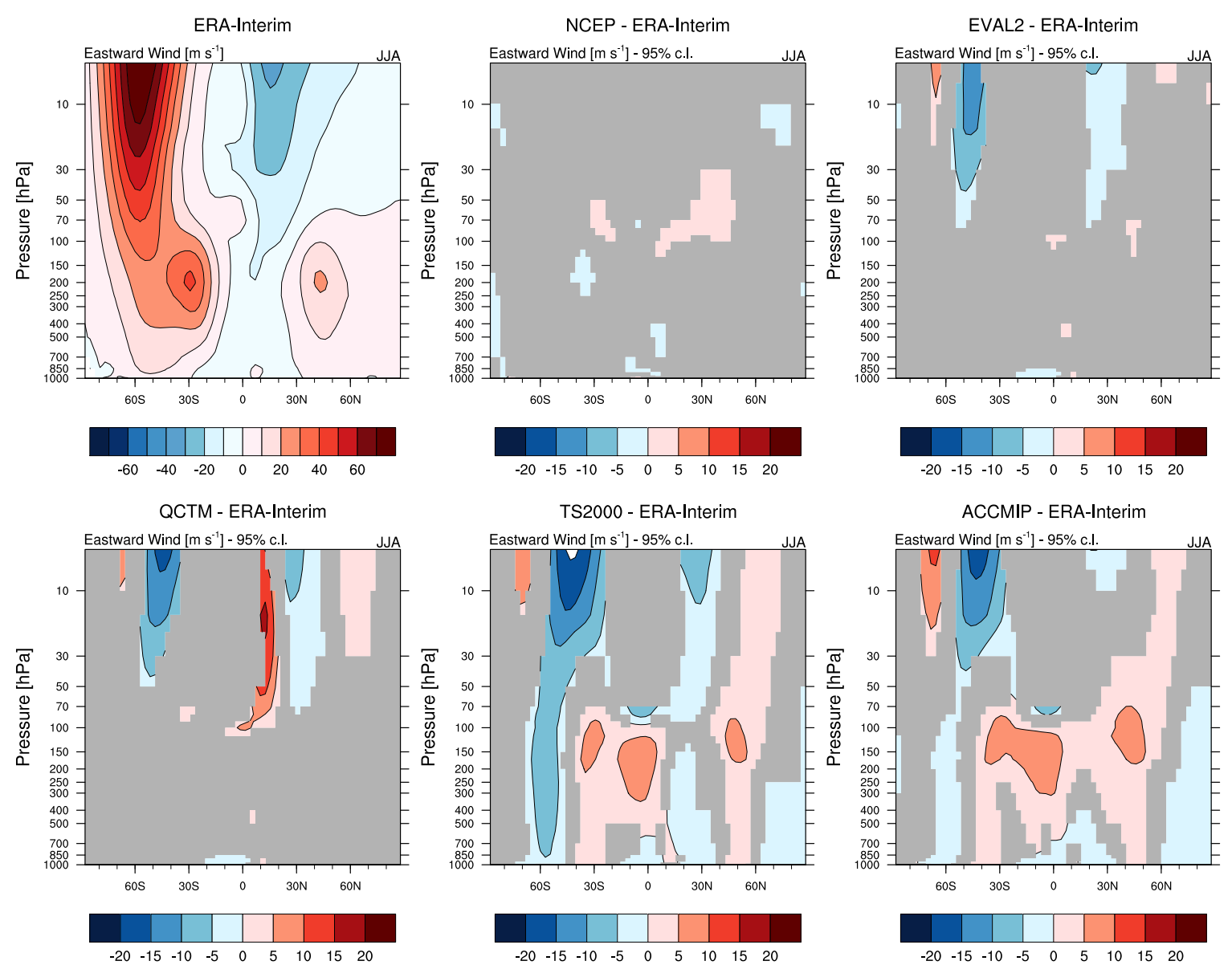

Figure S3: As in Fig. 9, for JJA mean. 

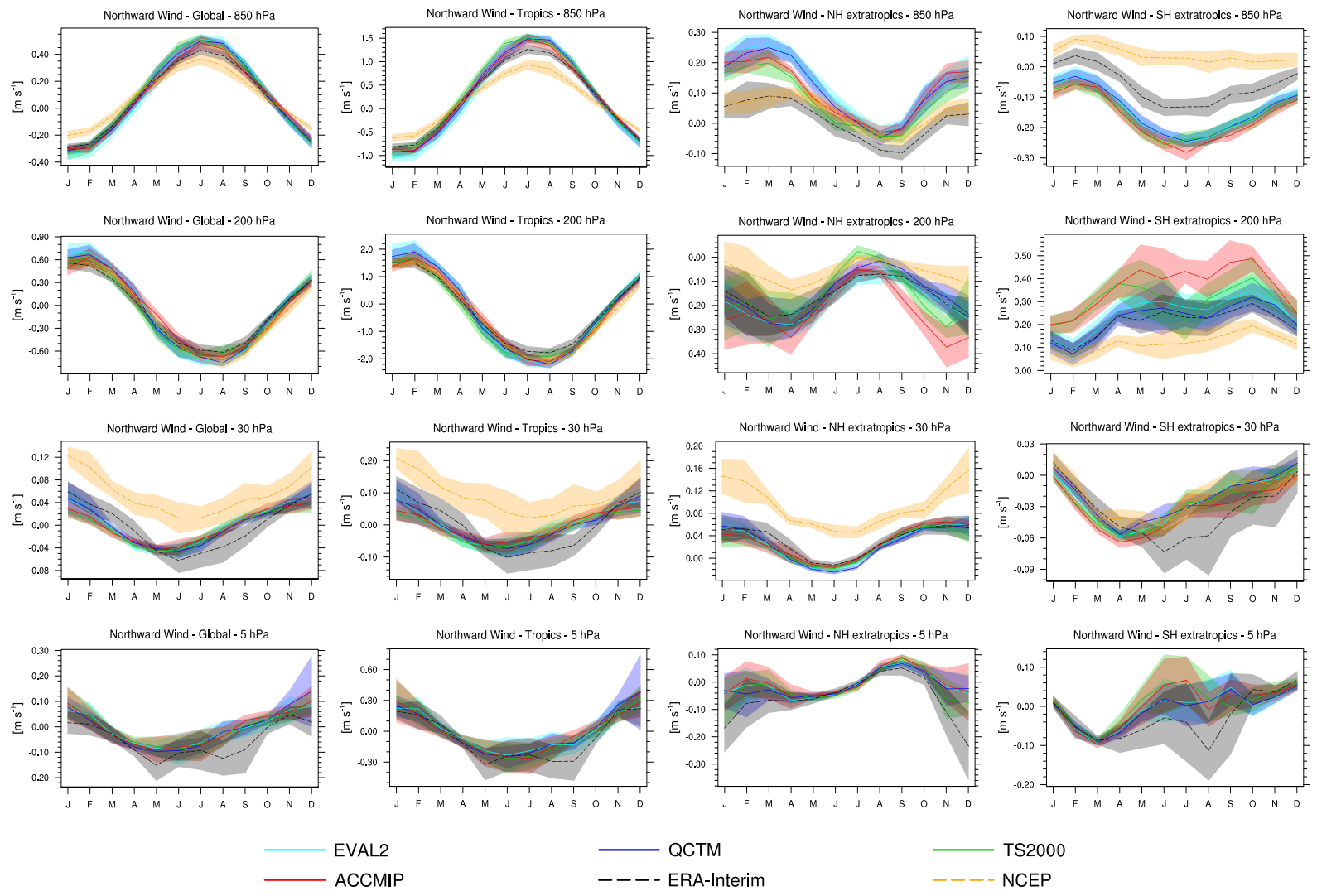

TS2000

Figure S4: As in Fig. 1, for northward wind. 

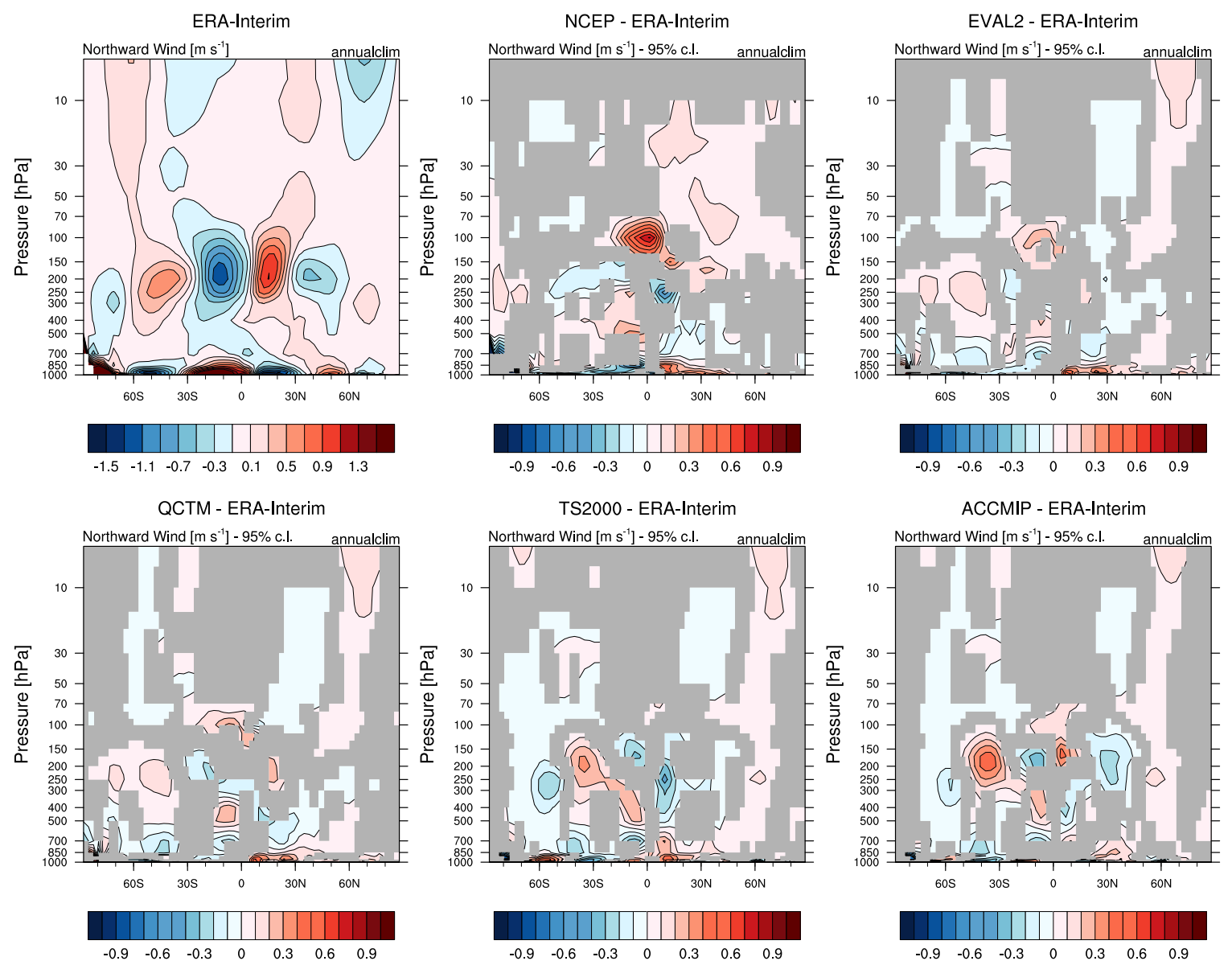

Figure S5: As in Fig. 2, for northward wind. 

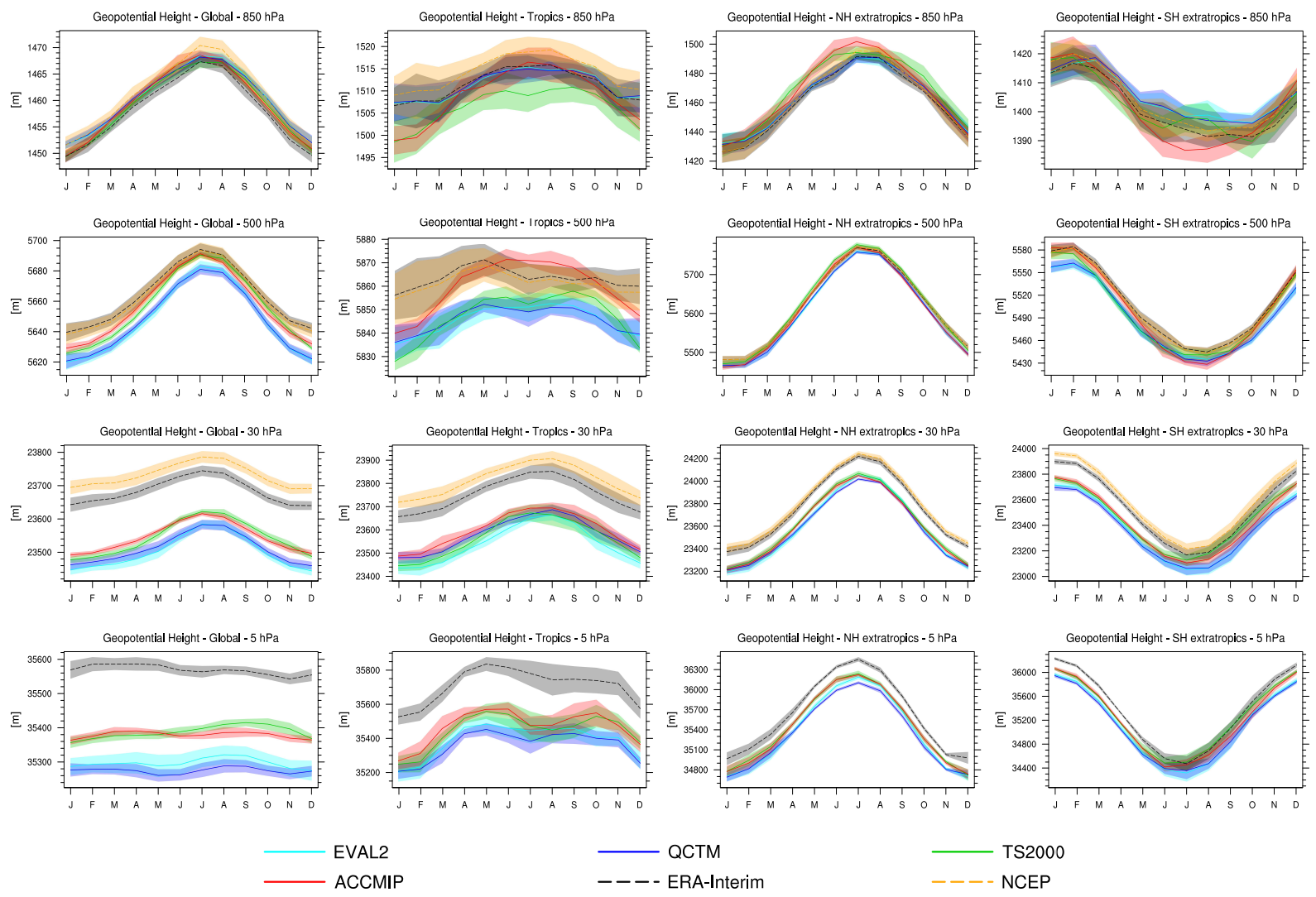

Figure S6: As in Fig. 1, for geopotential height. Note that the $500 \mathrm{hPa}$ level in considered instead of 200. 


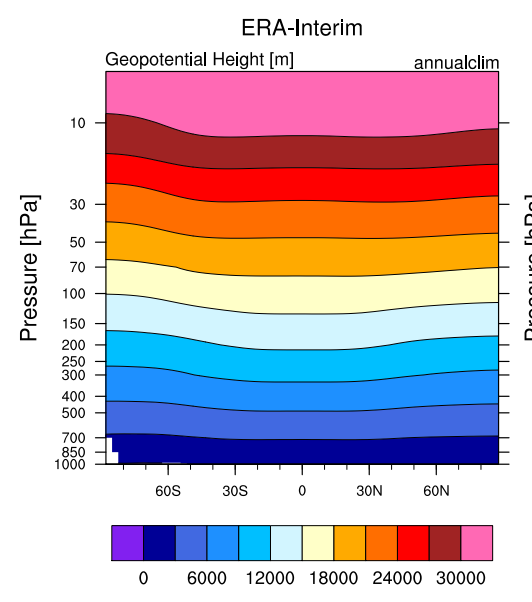

QCTM - ERA-Interim

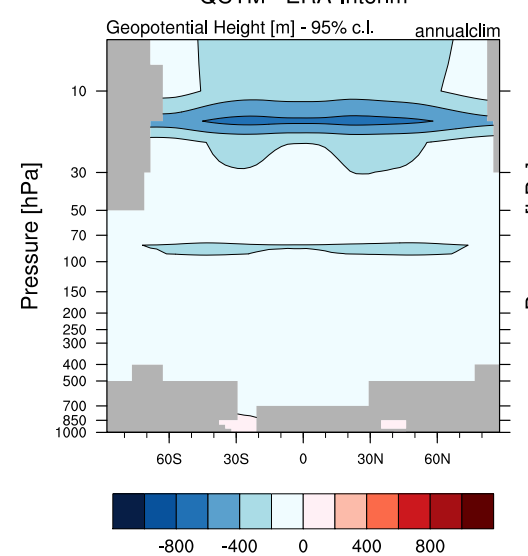

NCEP - ERA-Interim

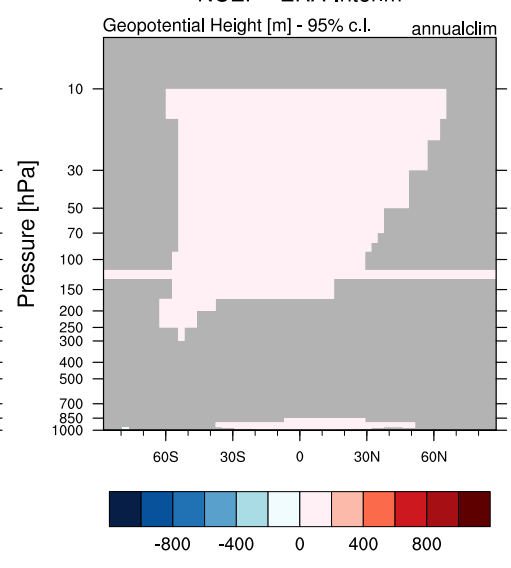

TS2000 - ERA-Interim

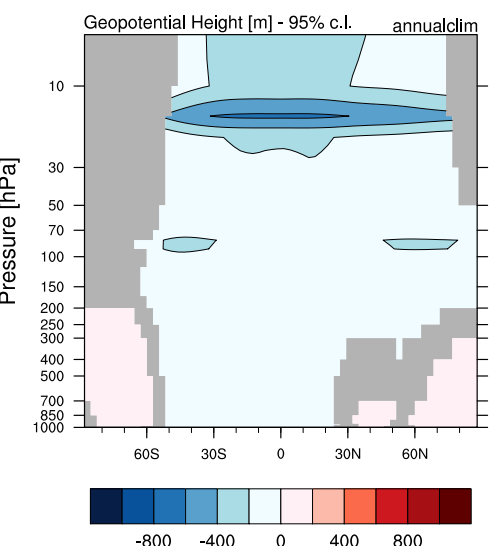

EVAL2 - ERA-Interim

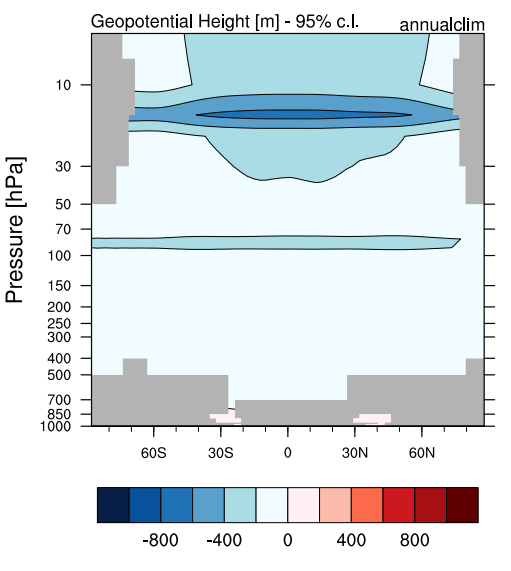

ACCMIP - ERA-Interim

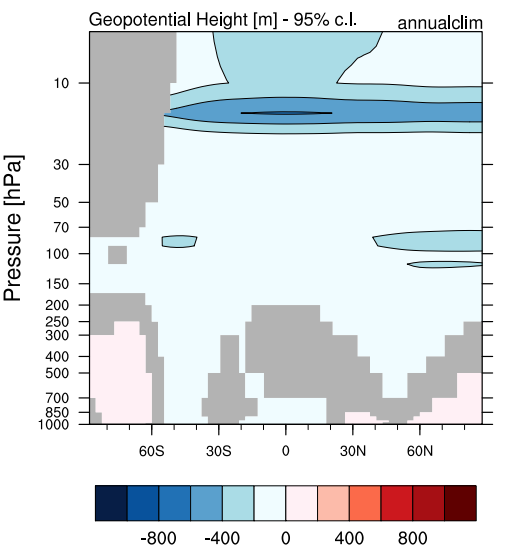

Figure S7: As in Fig. 2, for geopotential height. 

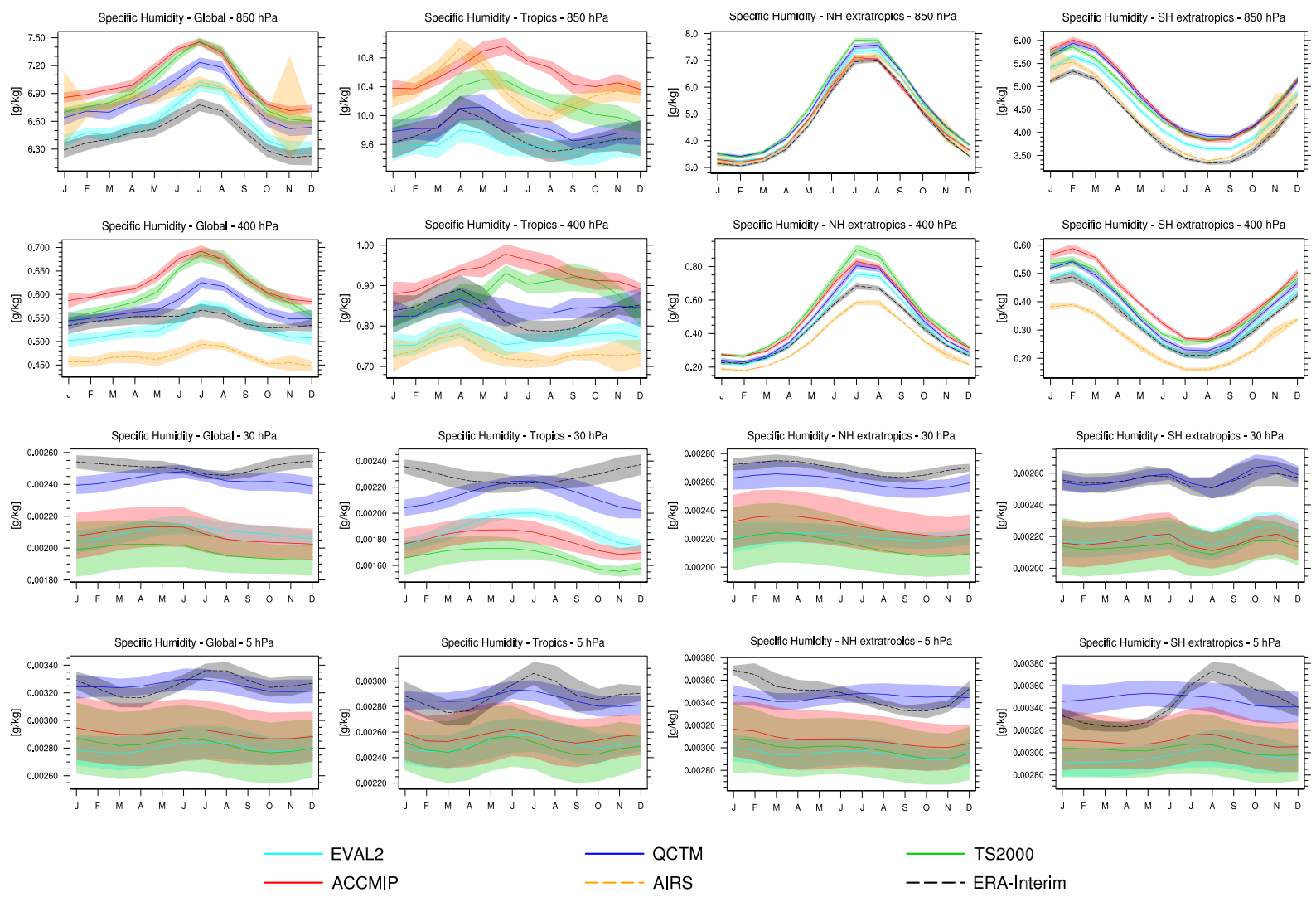

- TS2000
--- ERA-Interim

Figure S8: As in Fig. 1, for specific humidity. Note that the $400 \mathrm{hPa}$ level in considered instead of 200. 


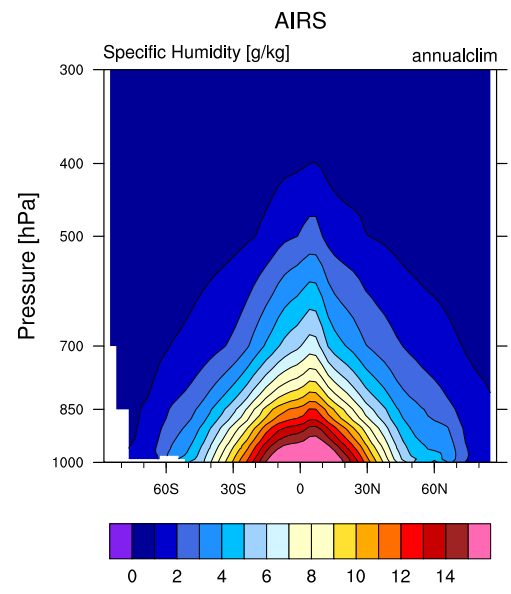

QCTM - AIRS

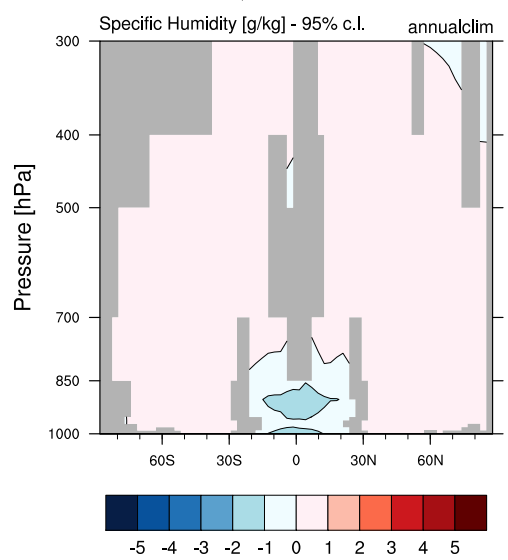

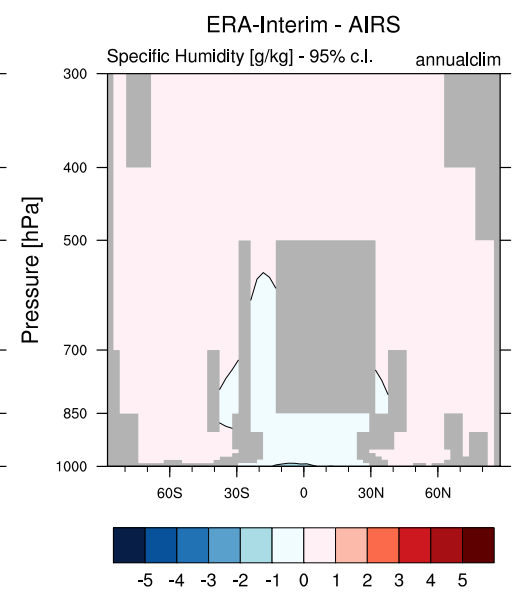

TS2000 - AIRS

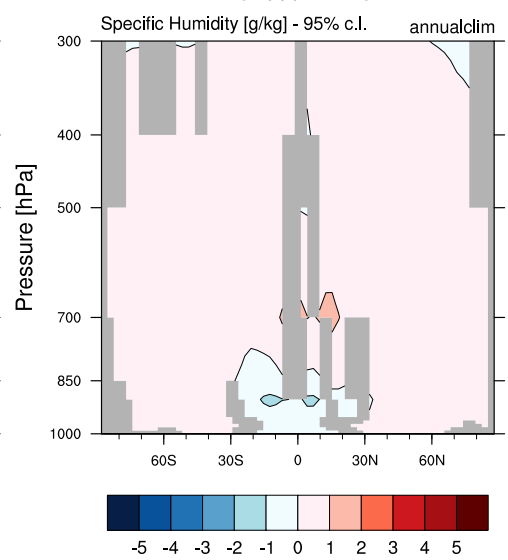

EVAL2 - AIRS

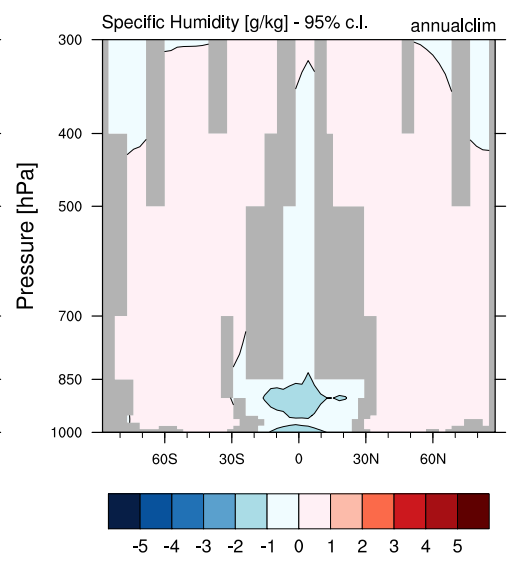

ACCMIP - AIRS

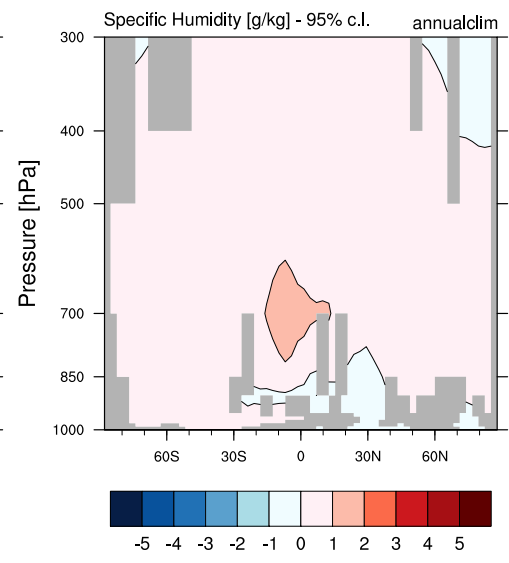

Figure S9: As in Fig. 2, for specific humidity. 

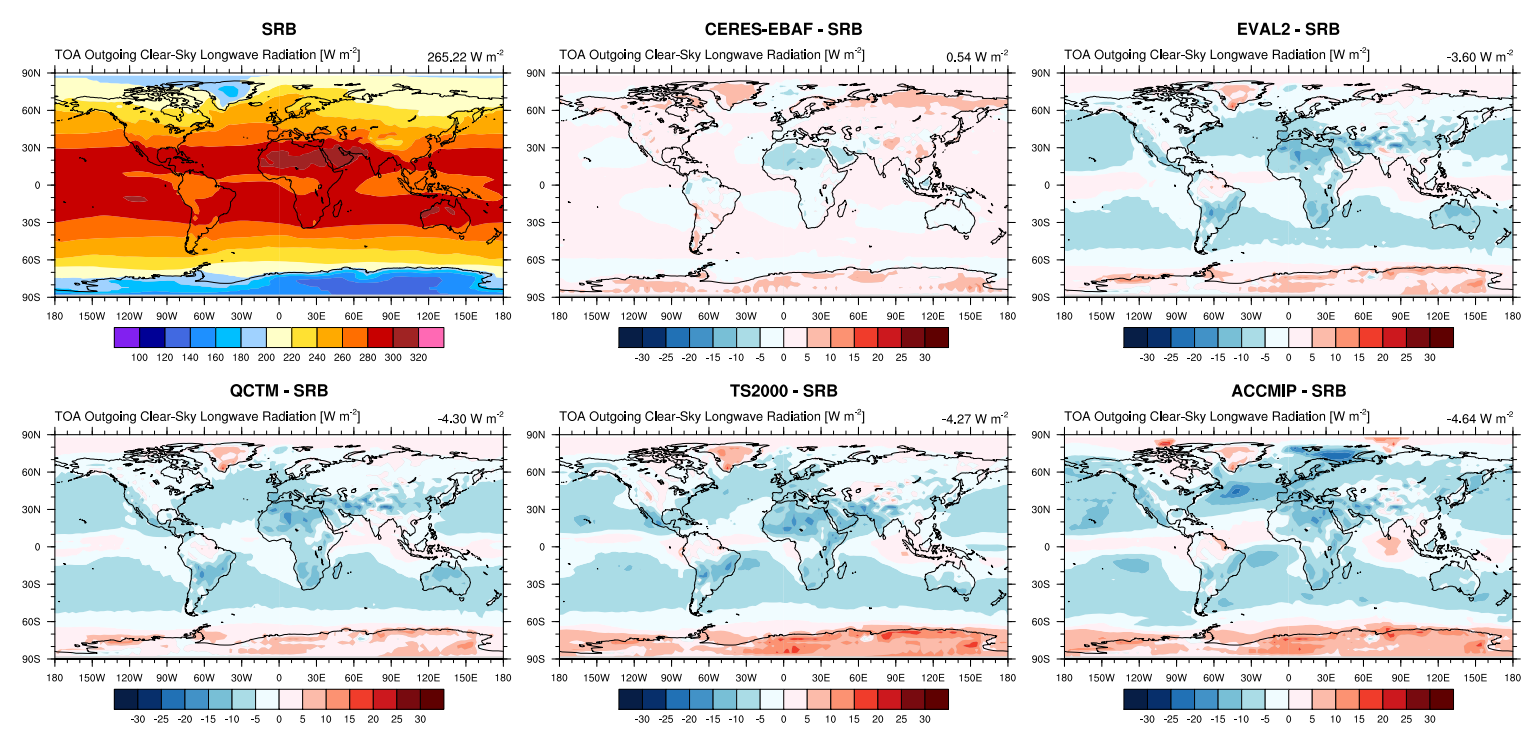

Figure S10: Annual mean clear-sky outgoing longwave radiation at TOA from SRB (upper left), differences from SRB data to CERES-EBAF data and to the EMAC simulations. The values on top of each panel show the global (area-weighted) average, calculated after regridding the data to the horizontal grid of the model.
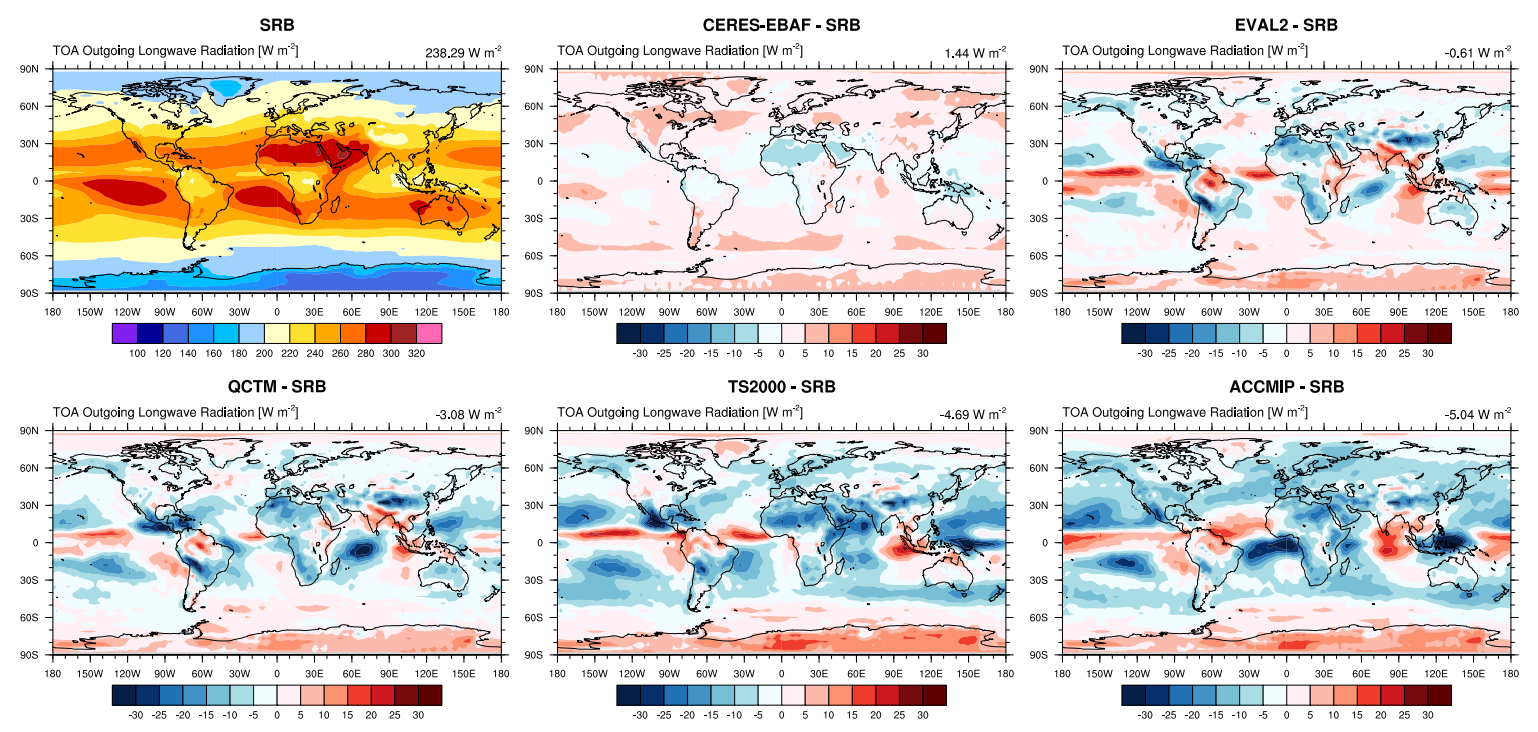

Figure S11: As in Fig. S10, for all-sky outgoing longwave radiation. 

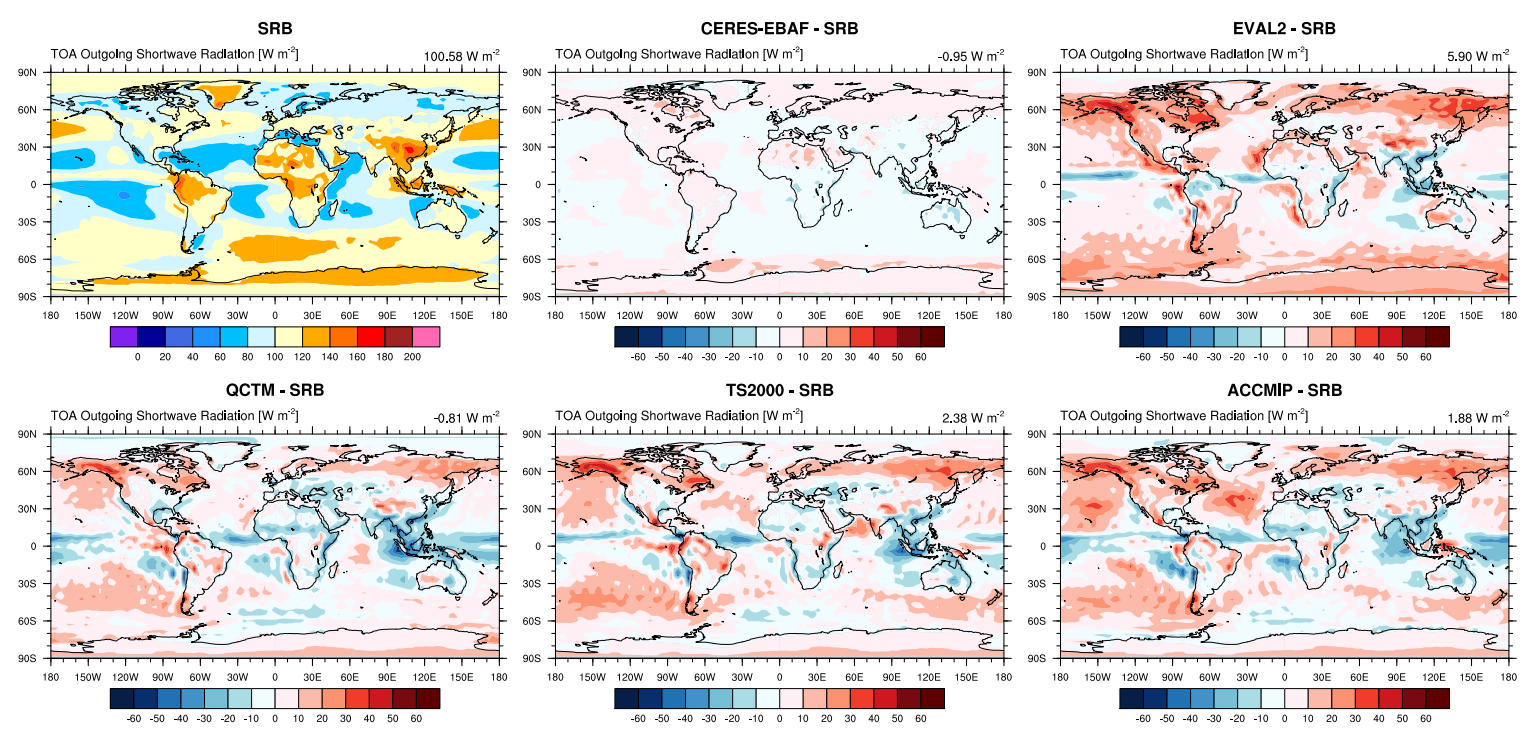

Figure S12: As in Fig. S10, for all-sky reflected shortwave radiation.
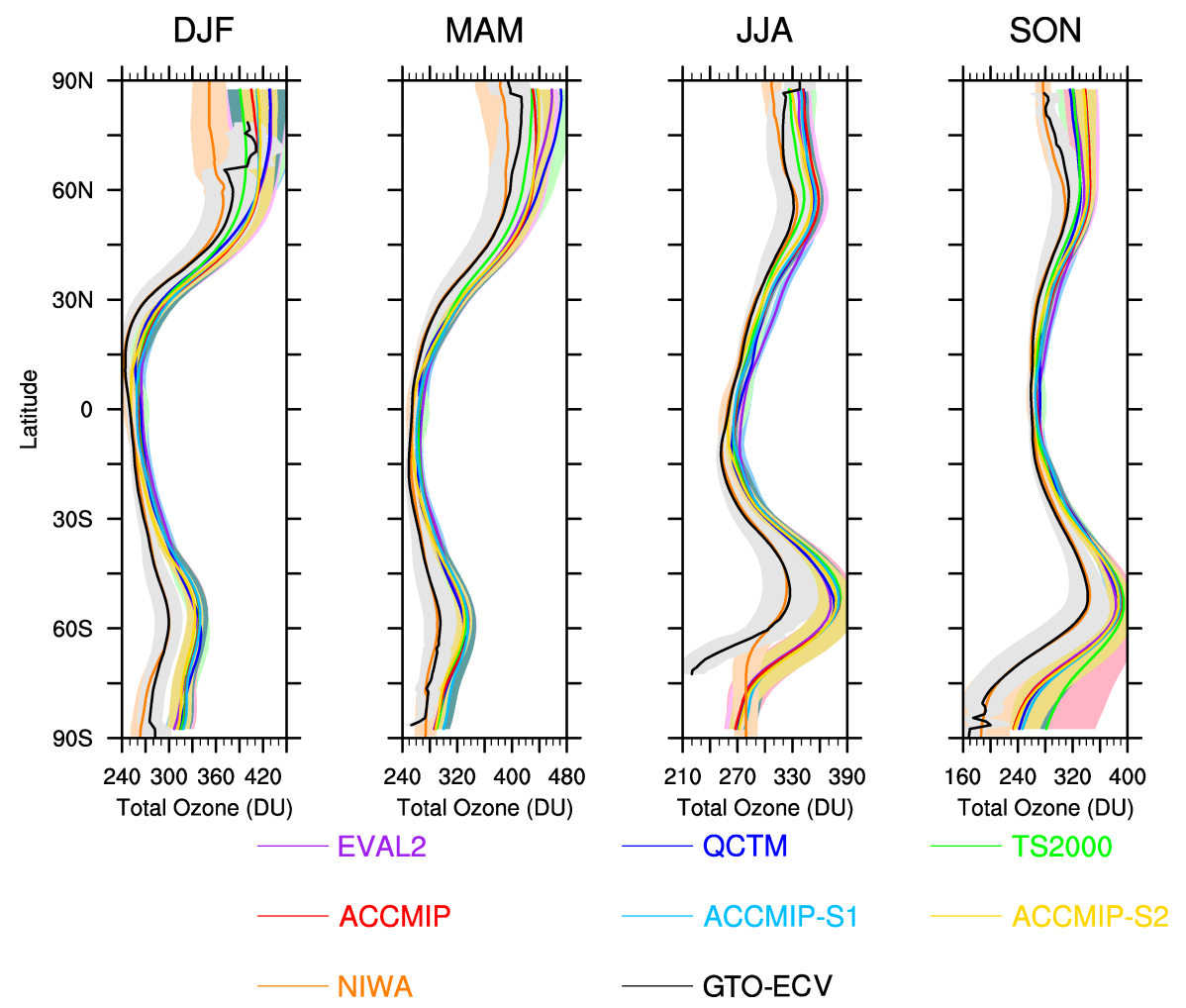

Annual mean

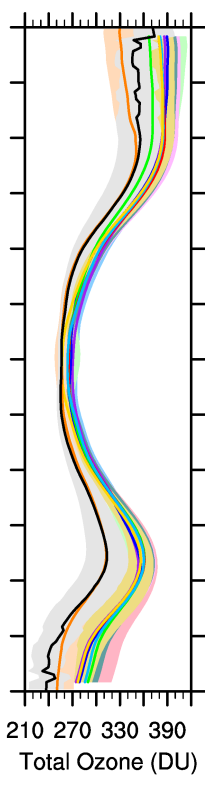

Figure S13: Zonal mean total ozone climatology for DJF, MAM, JJA, SON and the annual mean for the EMAC simulations compared to NIWA and GTO-ECV. Shaded areas indicate the $\pm 1 \sigma$ interannual variability. 


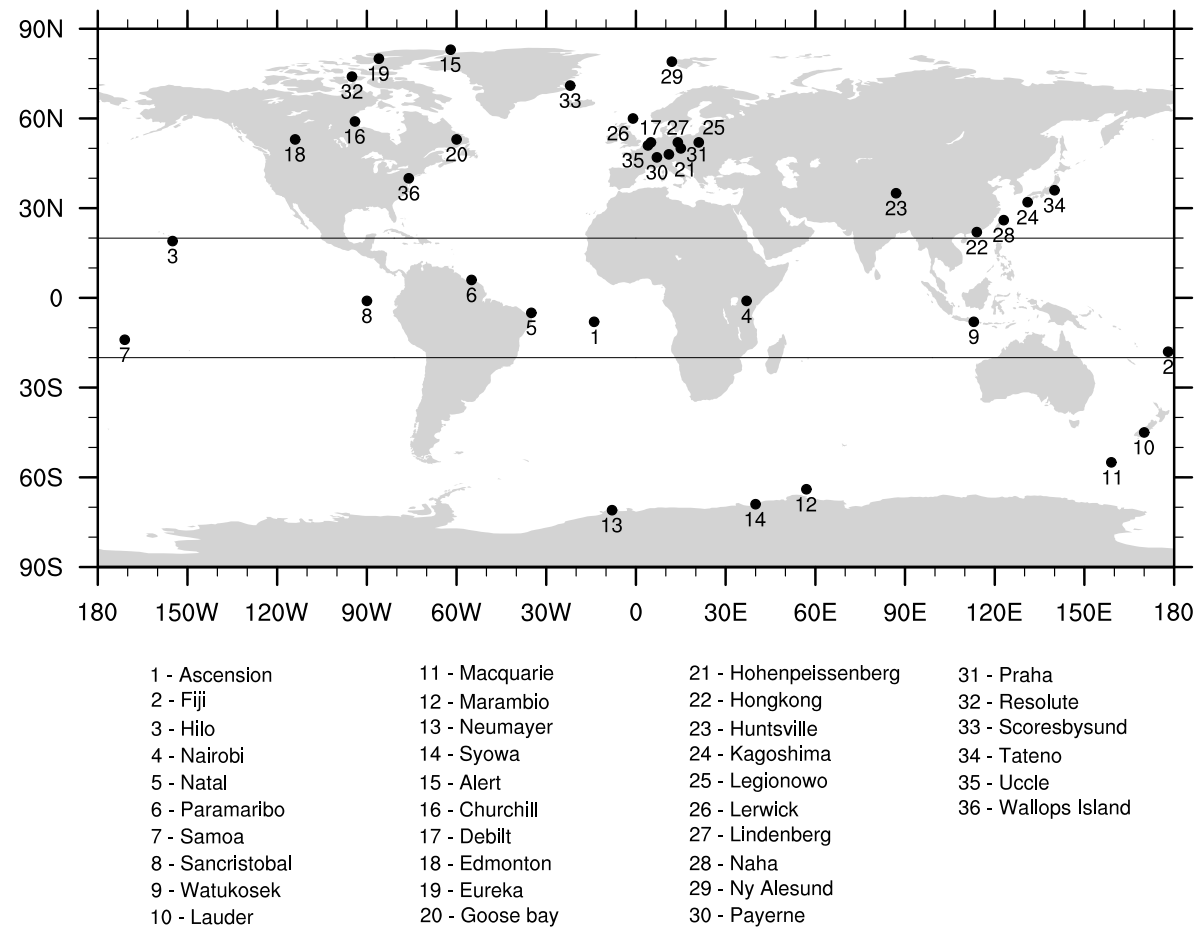

Figure S14: Location of the Tilmes ozonesondes stations used for the plots in Fig. 15. The horizontal lines delimit the three regions considered in the analysis: tropics, NH and SH extratropics. 
Boulder

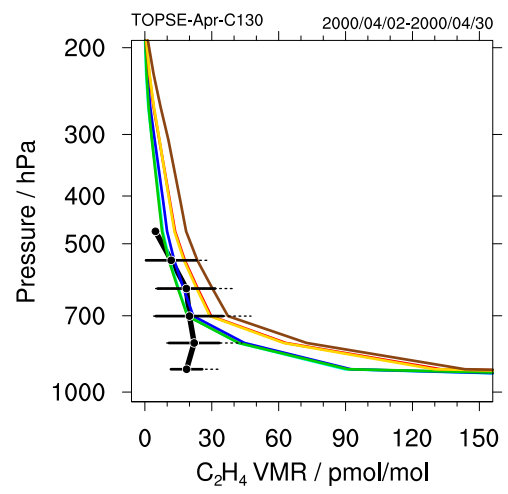

Fiji

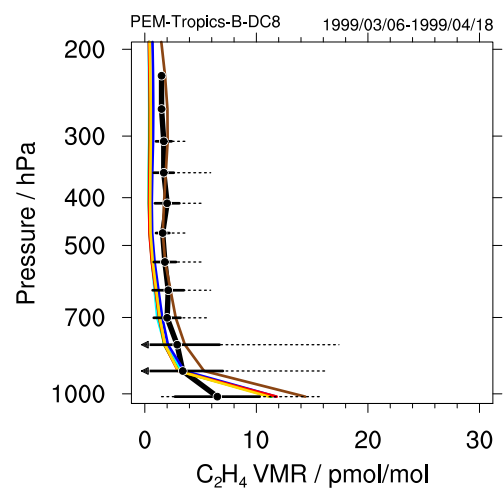

Emmons

TS2000

ACCMIP-S2
Churchill

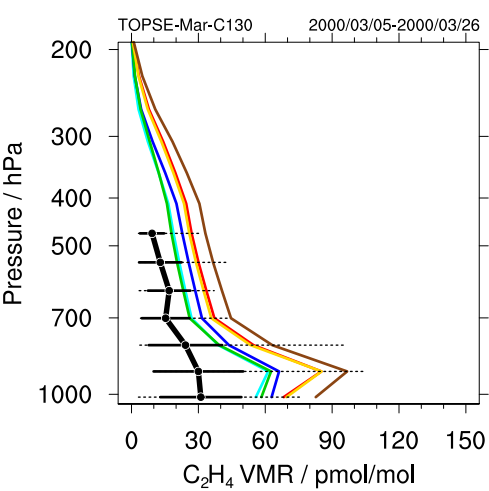

S-Atlantic

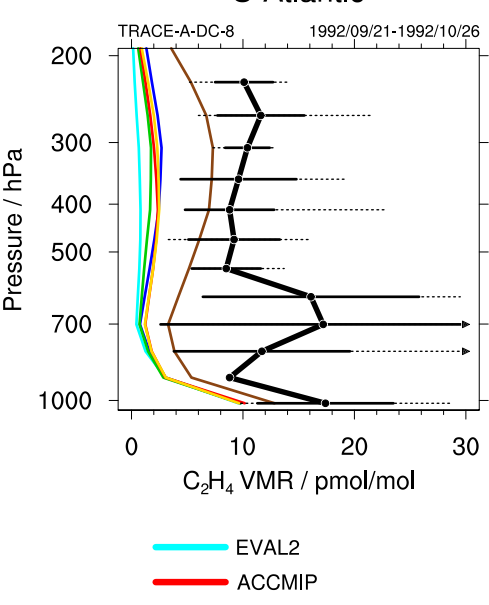

Thule

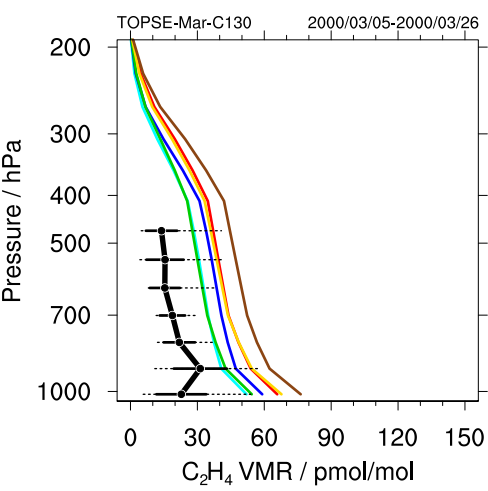

E-Brazil-Coast

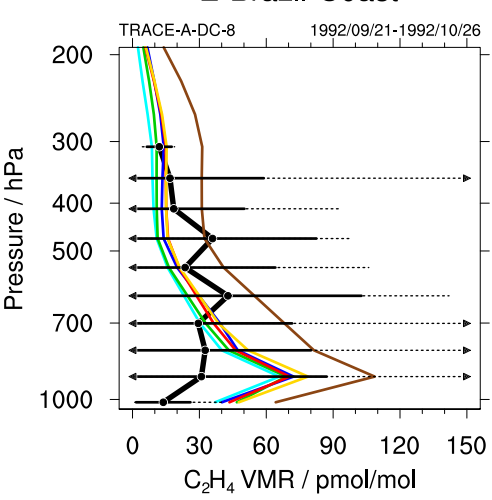

$\longrightarrow$ QCTM

ACCMIP-S

Figure S15: As in Fig. 16, for $\mathrm{C}_{2} \mathrm{H}_{4}$. 

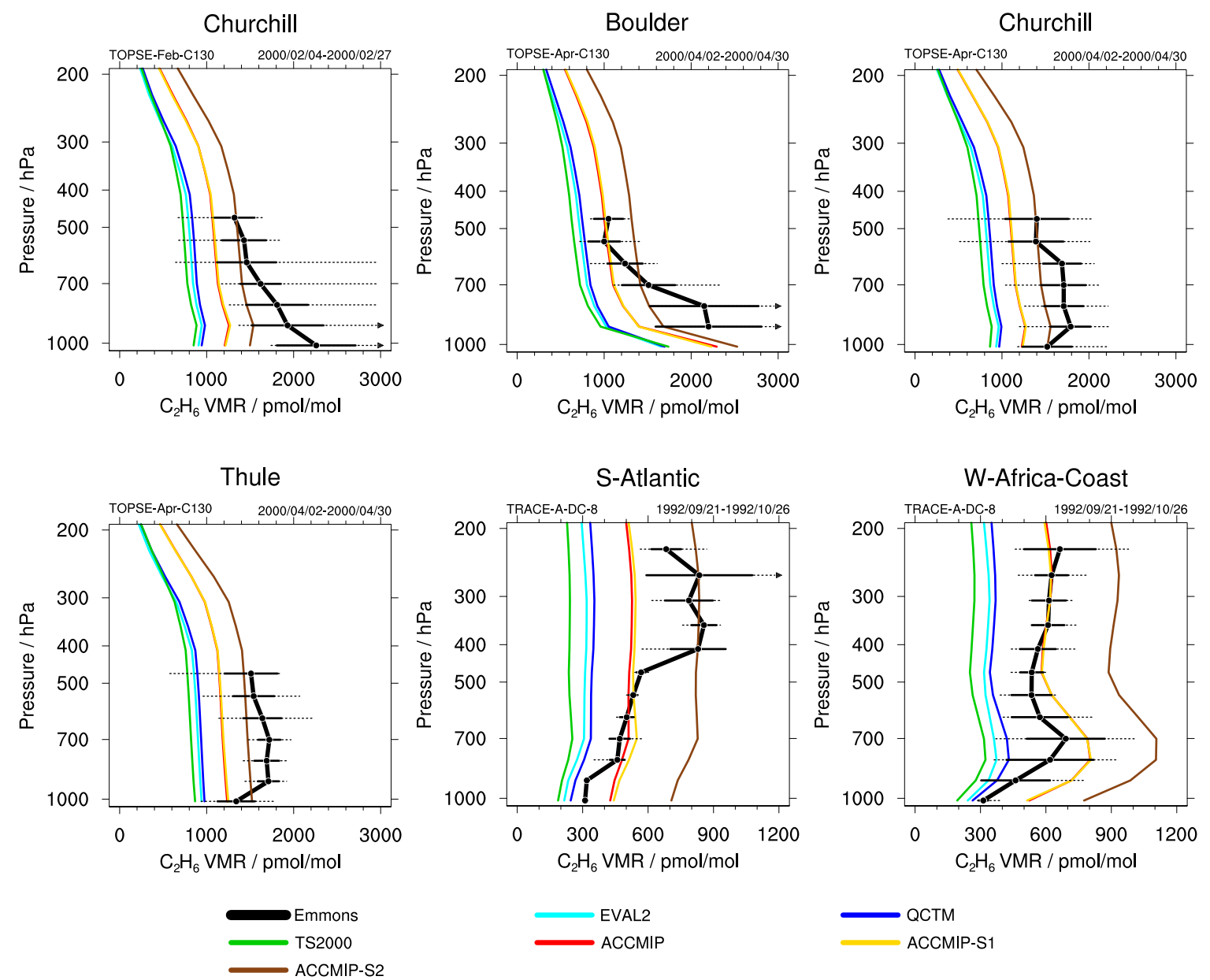

Figure S16: As in Fig. 16, for $\mathrm{C}_{2} \mathrm{H}_{6}$. 

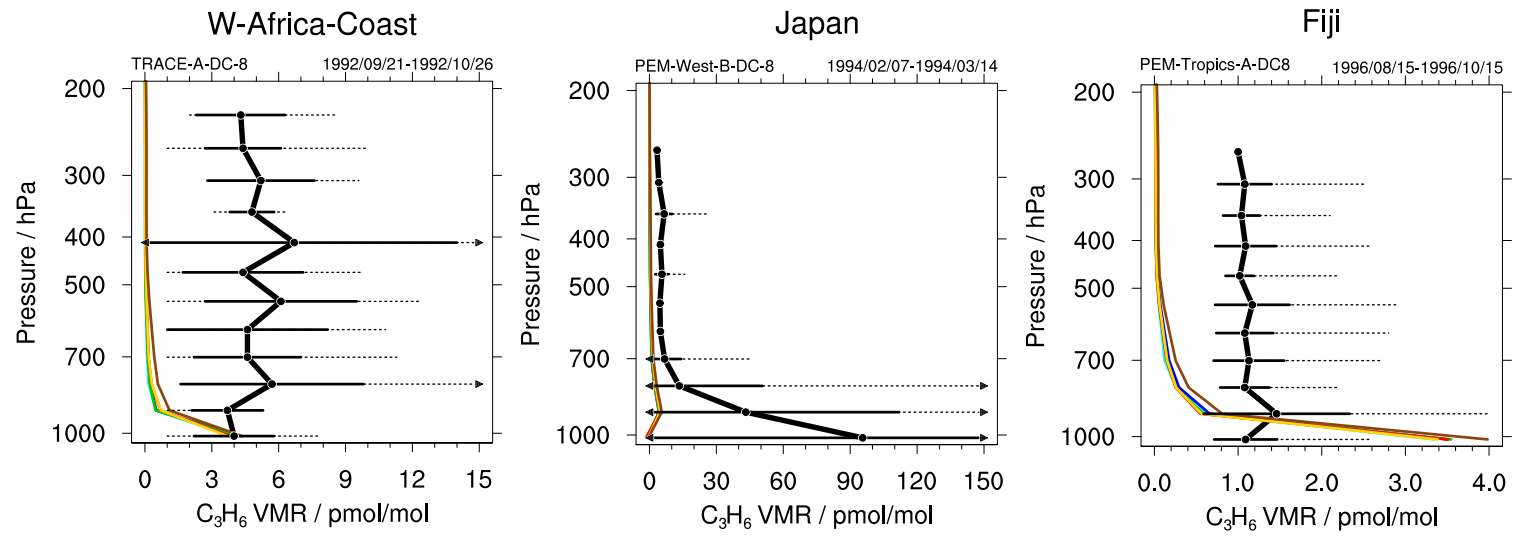

Easter-Island
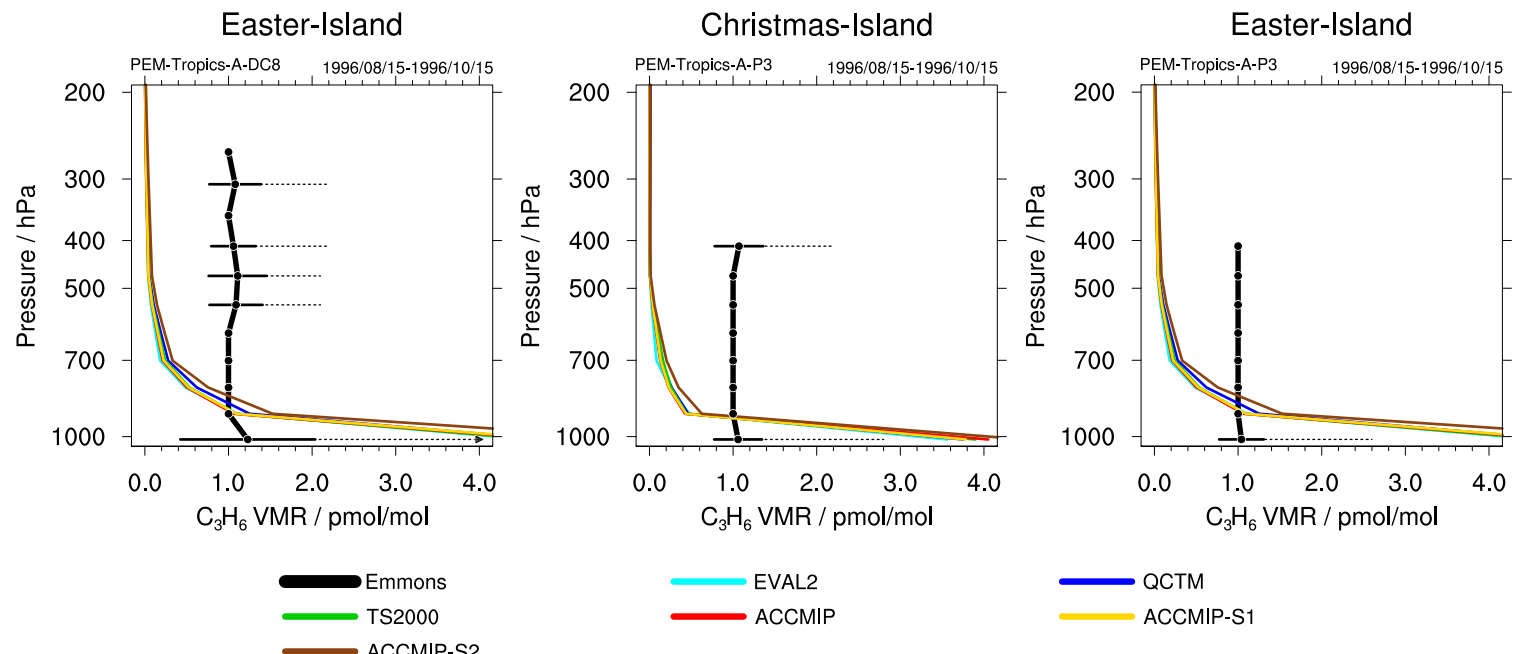

Figure S17: As in Fig. 16, for $\mathrm{C}_{3} \mathrm{H}_{6}$.
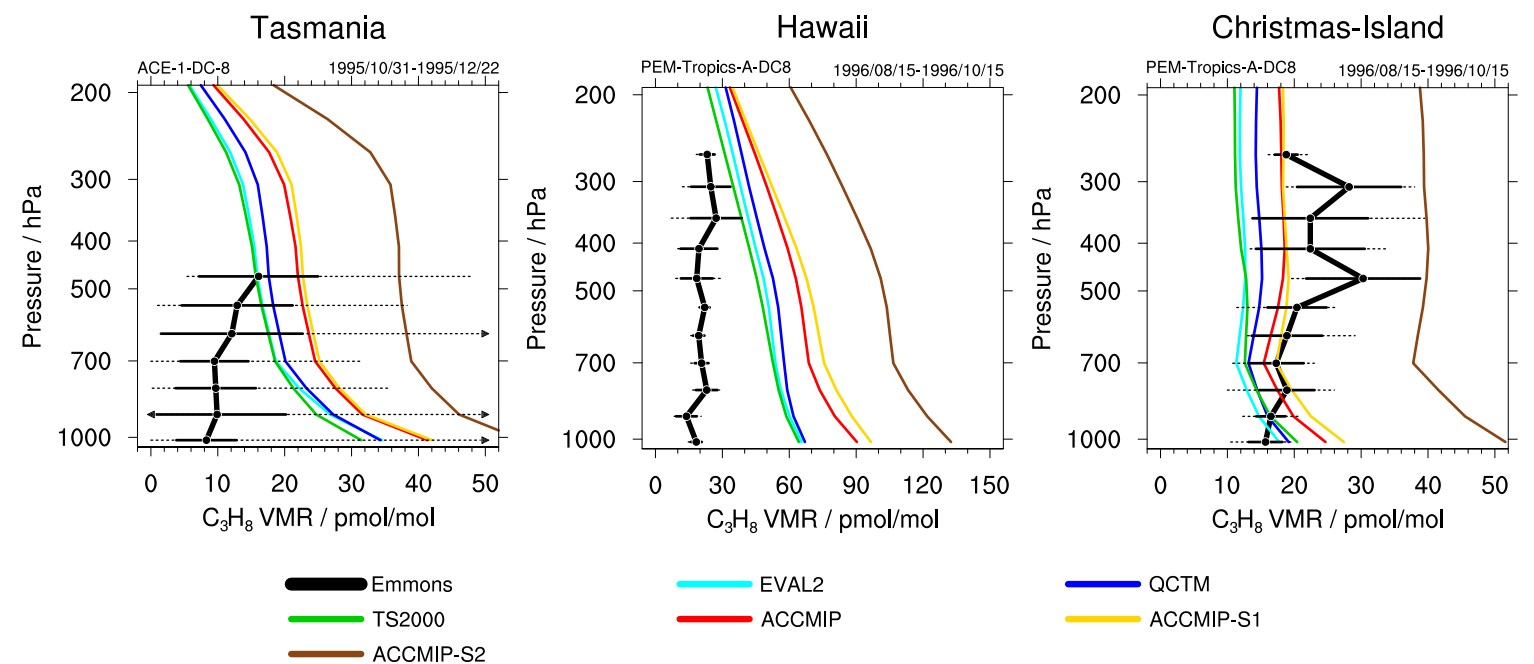

Figure S18: As in Fig. 16, for $\mathrm{C}_{3} \mathrm{H}_{8}$. 

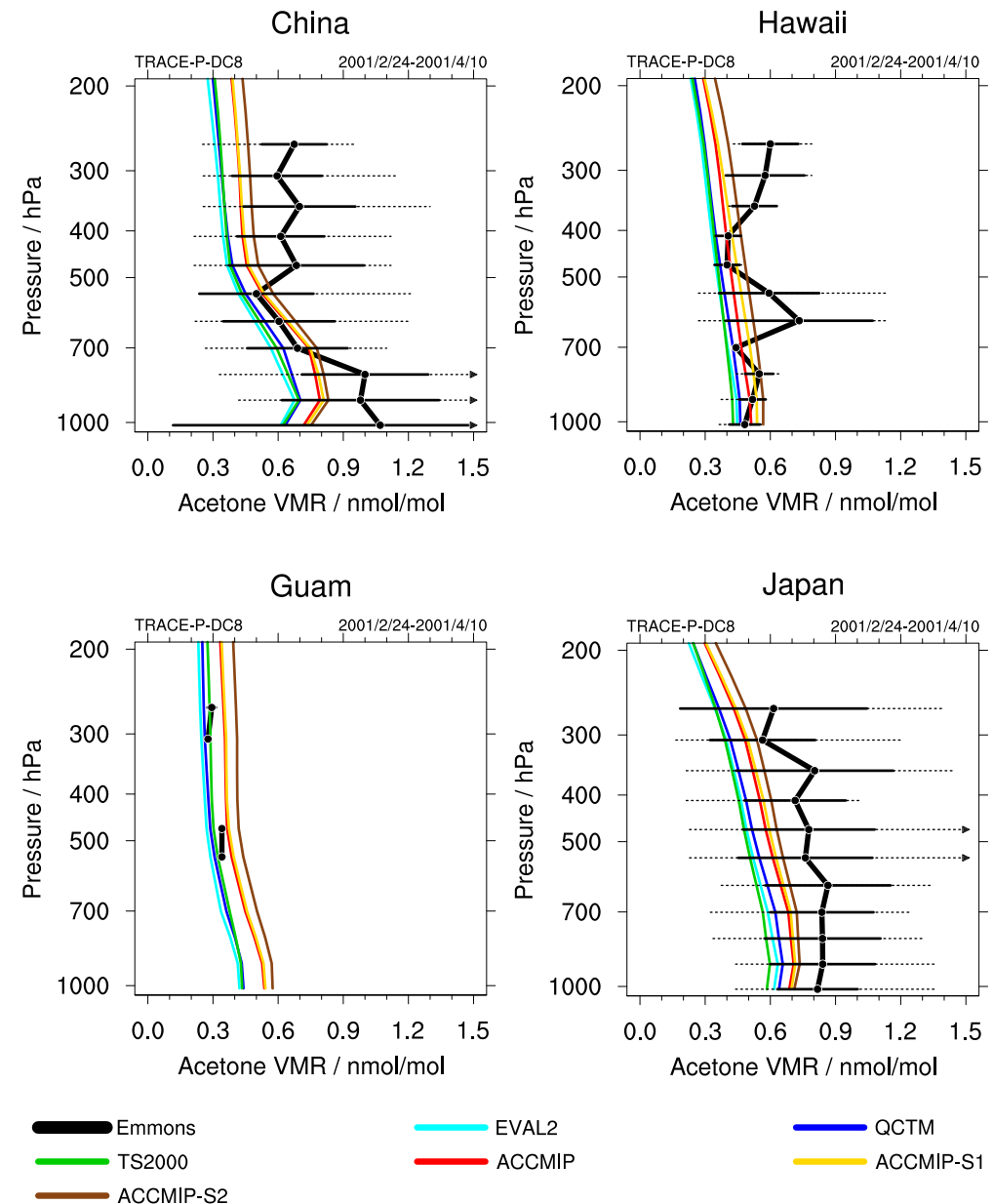

Figure S19: As in Fig. 16, for $\mathrm{CH}_{3} \mathrm{COCH}_{3}$ (acetone). 


\section{References}

Boyer, T., Stephens, C., Antonov, J., Conkright, M., Locarnini, R., O'Brien, T., and Garcia, H.: World Ocean Atlas 2001, Volume 2 Salinity, NOOA Atlas NESDIS 50, U.S. Government Printing Office, 2002.

Broadgate, W. J., Liss, P. S., and Penkett, S. A.: Seasonal emissions of isoprene and other reactive hydrocarbon gases from the ocean, Geophys. Res. Lett., 24, 2675-2678, doi: 10.1029/97GL02736, 1997.

Dentener, F., Kinne, S., Bond, T. C., Boucher, O., Cofala, J., Generoso, S., Ginoux, P., Gong, S. L., Hoelzemann, J. J., Ito, A., Marelli, L., Penner, J. E., Putaud, J.-P., Textor, C., Schulz, M., van Der Werf, G. R., and Wilson, J.: Emissions of primary aerosol and precursor gases in the years 2000 and 1750 prescribed data-sets for AeroCom, Atmos. Chem. Phys., 6, 4321-4344, doi:10.5194/acp-6-4321-2006, 2006.

Emmons, L. K., Hauglustaine, D. A., Mller, J.-F., Carroll, M. A., Brasseur, G. P., Brunner, D., Staehelin, J., Thouret, V., and Marenco, A.: Data composites of airborne observations of tropospheric ozone and its precursors, J. Geophys. Res., 105, 20 497-20 538, doi: 10.1029/2000JD900232, 2000.

Giorgetta, M. A. and Bengtsson, L.: Potential role of the quasi-biennial oscillation in the stratosphere-troposphere exchange as found in water vapor in general circulation model experiments, J. Geophys. Res., 104, 6003-6019, doi:10.1029/1998JD200112, 1999.

Grewe, V., Brunner, D., Dameris, M., Grenfell, J., Hein, R., Shindell, D., and Staehelin, J.: Origin and variability of upper tropospheric nitrogen oxides and ozone at northern midlatitudes, Atmos. Environ., 35, 3421-3433, doi:10.1016/S1352-2310(01)00134-0, 2001.

Guenther, A., Hewitt, C. N., Erickson, D., Fall, R., Geron, C., Graedel, T., Harley, P., Klinger, L., Lerdau, M., Mckay, W. A., Pierce, T., B, S., Steinbrecher, R., Tallamraju, R., Taylor, J., and Zimmerman, P.: A global model of natural volatile organic compound emissions, J. Geophys. Res., 100, 8873-8892, doi:10.1029/94JD02950, 1995.

Hoor, P., Caro, D., Dessens, O., Endresen, O., Gauss, M., Grewe, V., Hauglustaine, D. A., Isaksen, I. S. A., Lelieveld, J., Myhre, G., Meijer, E., Olivie, D., Prather, M. J., Schnadt Poberaj, C., Shine, K. P., Staehelin, J., Tang, Q., van Aardenne, J. A., van Velthoven, P., and Sausen, R.: The impact of traffic emissions on atmospheric ozone and $\mathrm{OH}$ : results from QUANTIFY, Atmos. Chem. Phys., 9, 3113-3136, doi:10.5194/acp-9-3113-2009, 2009.

Kerkweg, A., Sander, R., Tost, H., and Jöckel, P.: Technical Note: Implementation of prescribed (OFFLEM), calculated (ONLEM), and pseudo-emissions (TNUDGE) of chemical species in the Modular Earth Submodel System (MESSy), Atmos. Chem. Phys., 6, 3603-3609, doi: 10.5194/acp-6-3603-2006, 2006.

Kettle, A. J. and Andreae, M. O.: Flux of dimethylsulfide from the oceans: A comparison of updated data sets and flux models, J. Geophys. Res., 105, 26 793-26 808, doi: 10.1029/2000JD900252, 2000.

Lamarque, J.-F., Bond, T. C., Eyring, V., Granier, C., Heil, A., Klimont, Z., Lee, D. S., Liousse, C., Mieville, A., Owen, B., Schultz, M. G., Shindell, D. T., Smith, S. J., Stehfest, E., van Aardenne, J. A., Cooper, O. R., Kainuma, M., Mahowald, N., McConnell, J. R., Naik, V., Riahi, K., and van Vuuren, D. P.: Historical (1850-2000) gridded anthropogenic and biomass burning emissions of reactive gases and aerosols: methodology and application, Atmos. Chem. Phys., 10, 7017-7039, doi:10.5194/acp-10-7017-2010, 2010. 
Lean, J.: Evolution of the Sun's Spectral Irradiance Since the Maunder Minimum, Geophys. Res. Lett., 27, 2425-2428, doi:10.1029/2000GL000043, 2000.

Pozzer, A., Jöckel, P., Sander, R., Williams, J., Ganzeveld, L., and Lelieveld, J.: Technical Note: The MESSy-submodel AIRSEA calculating the air-sea exchange of chemical species, Atmos. Chem. Phys., 6, 5435-5444, doi:10.5194/acp-6-5435-2006, 2006.

Pozzer, A., Jöckel, P., and Van Aardenne, J.: The influence of the vertical distribution of emissions on tropospheric chemistry, Atmos. Chem. Phys., 2, 961-987, doi:10.5194/acp-12961-2012, 2009.

Price, C. and Rind, D.: Modeling Global Lightning Distributions in a General Circulation Model, Mon. Wea. Rev., 122, 1930-1939, doi:0.1175/1520-0493(1994)122;1930:MGLDIA ¿2.0.CO;2, 1994.

Prinn, R. G., Weiss, R. F., Fraser, P. J., Simmonds, P. G., Cunnold, D. M., Alyea, F. N., Doherty, S. O., Salameh, P., Miller, B. R., Huang, J., Wang, R. H. J., Hartley, D. E., Harth, C., Steele, L. P., Sturrock, G., Midgley, P. M., and McCulloch, A.: A history of chemically and radiatively important gases in air deduced from ALE/GAGE/AGAGE, J. Geophys. Res., 105, 17 751-17 792, doi:10.1029/2000JD900141, 2000.

Schmitt, A. and Brunner, B.: Emissions from aviation and their development over time, in: Pollutants from Air Traffic - Results of Atmospheric Research 19921997, edited by Schumann, U., Chlond, A., Ebel, A., Krcher, B., Pak, H., Schlager, H., Schmitt, A., and Wendling, P., pp. 37-52, DLR-Mitteilung 97-04, Deutsches Zentrum fr Luft- und Raumfahrt, Cologne, Germany, 1997.

Spiro, P. A., Jacob, D. J., and Logan, J. A.: Global inventory of sulfur emissions with $1^{\circ} \times 1^{\circ}$ resolution, J. Geophys. Res., 97, 6023-6036, doi:10.1029/91JD03139, 1992.

Tanre, D., Geleyn, J.-F., and Slingo, J.: First results of the introduction of an advanced aerosolradiation interaction in the ECMWF low resolution global model, in: Aerosols and their climatic effects, edited by Gerber, H. and Deepak, A., pp. 133-177, A. Deepak Publ., 1994.

Vignati, E., Wilson, J., and Stier, P.: M7: An efficient size-resolved aerosol microphysics module for large-scale aerosol transport models, J. Geophys. Res., 109, doi:10.1029/2003JD004485, 2004 .

von Kuhlmann, R., Lawrence, M. G., Crutzen, P. J., and Rasch, P. J.: A model for studies of tropospheric ozone and nonmethane hydrocarbons: Model description and ozone results, J. Geophys. Res., 108, 4294, doi:10.1029/2002JD002893, 2003. 